\title{
Translation, cultural adaptation and evaluation of the psychometric properties of the Falls Risk Awareness Questionnaire (FRAQ): FRAQ-Brazil
}

\begin{abstract}
Anália R. Lopes ${ }^{1}$, Celita S. Trelha ${ }^{2}$
ABSTRACT | Objective: This study aimed to translate and culturally adapt the Falls Risk Awareness Questionnaire (FRAQ) for the elderly Brazilian population as well as to evaluate the internal consistency and reliability of this instrument. Method: The study used internationally accepted guidelines for the cross-cultural adaptation process. The questionnaire in its final Portuguese version was then applied to 120 elderly people to assess the measurement properties. The participants were interviewed twice in the first assessment (examiners 1 and 2 at an interval of 30 to 60 minutes) and again after 2 to 7 days by examiner 1. The internal consistency was assessed with Cronbach's alpha coefficient. To evaluate the reliability of the intra- and inter-evaluators, the Kappa coefficient for categorical variables was used; for numeric variables, the intra-class correlation coefficient (2-way mixed model) and the respective 95\% confidence intervals were used in addition to the concordance test of Bland and Altman. Results: The Brazilian version of the FRAQ was obtained while maintaining a semantic, idiomatic, cultural and conceptual equivalence. The internal consistency was $\alpha=0.95$, while for intra-examiner reliability, an intrarater correlation coefficient (ICC-3,1) of 0.91 was obtained with an intra-class correlation Kappa coefficient of 0.89 and a Bland and Altman mean difference (bias) of -0.52 . Regarding the inter-examiner reliability, the $\mathrm{ICC}=0.78$, Kappa $=0.76$ and bias $=0.12$. Conclusions: The translation and cultural adaptation of the FRAQ for the elderly Brazilian population was successfully performed. The instrument demonstrated excellent reliability and internal consistency, thus making it useful for assessing the perception of the risk of a fall among elderly Brazilians.
\end{abstract}

Keywords: questionnaires; translations; reproducibility of results; accidental falls; physical therapy.

\section{HOW TO CITE THIS ARTICLE}

Lopes AR, Trelha CS. Translation, cultural adaptation and evaluation of the psychometric properties of the Falls Risk Awareness Questionnaire (FRAQ): FRAQ-Brazil. Braz J Phys Ther. 2013 Nov-Dec; 17(6):593-605. http://dx.doi.org/10.1590/ S1413-35552012005000128

\section{Introduction}

An aging population is a worldwide phenomenon, but the Brazilian elderly population is growing at a faster rate than that observed in developed countries. It is estimated that in 2025, Brazil will have the sixth largest elderly population in the world ${ }^{1-3}$. An increase in life expectancy is related to a high rate of comorbidities ${ }^{4}$; in this context, falls and instability are among the geriatric syndromes that encompass the most frequent changes in the health of the elderly.

Falls and the consequent injuries are a public health problem of great social impact that is faced today by all countries with a significant aging population $^{5,6}$. This is a reality not only because of the high prevalence of falls per year, which in Brazil is between $27 \%$ and $35 \%$, but also because of the resulting morbidity and mortality and the high social and economic costs resulting from the subsequent injuries. At the same time, this type of public health problem is preventable given the factors that can be changed ${ }^{1,9,10}$.

A fall is the most serious and frequent domestic accident among the elderly, and falling is the main cause of accidental death in people over 65 years old ${ }^{11}$. In addition, a fall may be responsible for a decline in functional capacity, greater dependency, a poor quality of life and a higher risk for institutionalization ${ }^{7,9}$, in addition to the high costs to the health system ${ }^{6}$.

In this context, several studies are being performed that aim to prevent falls among the elderly ${ }^{12-16}$, allowing some organizations, such as the American Geriatrics Society, the British Geriatrics Society ${ }^{17,18}$ and the Brazilian Society of Geriatrics and Gerontology ${ }^{7}$, to develop guidelines to prevent falls with strategies based on scientific evidence. 
Although there are already several identified and proven risk factors, the development of a unique tool that predicts falls is still difficult, most likely because of the multifactorial etiology of falls, i.e., falls are derived from a combination of intrinsic, behavioral - related to the activities - and environmental factors ${ }^{5,7,17}$, which require a multifactorial assessment.

In addition, in evaluating the risk factors for falls in the elderly, it is critical to know the degree to which the individual is aware of or has knowledge of such risks because preventive changes cannot take place unless there is an awareness of the potential problems.

The Falls Risk Awareness Questionnaire (FRAQ) is a questionnaire that aims to evaluate the perception of the risk for falls in individuals over 65 years old. The instrument was developed at the University of Alberta, Canada and contains 26 multiple-choice closed-ended questions and 2 open-ended questions and is divided into 2 parts. The first part contains 3 questions to be administered by the interviewer, and the second part contains 25 questions to be answered individually by the interviewee. All the 26 multiple-choice questions have only 1 correct answer. Because 1 question about medications contains 8 correct answers and 1 question does not include an answer key, the questionnaire score ranges from 0 to 32 points; the higher the score, the better the awareness of falling risks of that elderly person. The instrument has construct validity ${ }^{19}$ and reasonable test-retest reliability ${ }^{20}$. In addition to Portuguese, the translation of the FRAQ into Chinese has been requested and is currently in progress.

This study aimed to translate and culturally adapt the Falls Risk Awareness Questionnaire (FRAQ) for the elderly Brazilian population and evaluate the internal consistency and reliability of this instrument. To allow collaborative research in future systematic reviews of reliability studies, this manuscript was prepared according to the guidelines for reporting reliability and agreement studies proposed by Kottner et al. ${ }^{21}$ in 2011.

The use of the FRAQ-Brazil will lead to knowledge of the awareness among the elderly of the risk factors for falling and, thereby, enable the development of educational programs that will improve understanding in this important area and optimize a preventive approach. This translation will also allow comparisons between elderly populations from different countries.

\section{Method}

\section{Type of study}

This is a cross-sectional methodological study of a transcultural adaptation and an evaluation of the psychometric properties of the FRAQ that was approved by the Research Ethics Committee of the Universidade Estadual de Londrina (UEL), Londrina, Parana State, Brazil (Opinion 009/2012, CAAE 0346.0.268.000-11) and was authorized by the authors of the original FRAQ.

\section{Population and sample}

The calculation of the sample size was performed according to the formula [total $\mathrm{n}=\left(\mathrm{Z} \alpha_{12}\right)^{2} \times \mathrm{p}(1-\mathrm{p}) /$ $\left.\mathrm{e}^{2}\right]^{22}$. Considering an expected prevalence $(\mathrm{p})$ of approximately $7.4 \%$ of the population that is over 65 years old in Brazil, according to the 2010 Census $^{23}$, a confidence interval $\mathrm{Z}_{12}=1.96$ and an acceptable margin of error of $5 \%(\mathrm{e}=0.05)$, an $\mathrm{n}=105.3$ was obtained. Taking into account possible losses, a sample $10 \%$ larger was chosen, and 120 elderly persons were studied.

The study included patients aged 65 years or older of both genders, who were enrolled in the Family Health Program (FHP) of the city of Londrina, Parana State, Brazil, who presented sufficient cognitive conditions as assessed by the Mini Mental State Examination (MMSE) and who agreed to participate of the study by signing the free and informed consent form after an explanation of the goals and methods of the study by the researcher.

According to many authors ${ }^{24-26}$, the level of education should be considered in choosing the most appropriate MMSE cutoff score; therefore, based on the study of Lawrence and Veras ${ }^{26}$, we considered a cutoff score of 19 for illiterate and 25 for literate (with more than 4 years of schooling).

We excluded elderly people who did not achieve the minimum MMSE score, elderly patients with hearing and/or visual deficiencies identified at the time of the interview, individuals with Alzheimer's disease or any other neurological deficit that could compromise cognition and the patients who did not agree to participate in the study at time of the visit.

\section{Procedures}

The methodological procedures for the translation and cultural adaptation of the FRAQ were developed according to the guidelines proposed by Beaton et al. ${ }^{27}$, which are international standards designed to maintain the equivalence between the 
original source and the target versions. The proposal comprises 6 steps that are described below.

\section{Stages I and II: Initial translation into Portuguese and synthesis of the two translations}

The first stage was the translation of the instrument from English to Brazilian Portuguese. For that purpose, 2 independent translations (T1 and T2) were made by 2 bilingual translators, whose mother tongue was Portuguese. Only one of the translators was sworn in and was informed about the concepts involved in the research, while the other translator had no knowledge of such concepts. The translators developed written reports on the difficulties encountered and the justification of the translation choices.

The translators and the investigator met with the aim of producing a common version of the translation (T12), a summary version obtained from the analysis of the independent translations. In this version, the goal was a consensus among the translators rather than any personal opinion. A written report was produced to document the entire process of the summary version.

\section{Stage III: Back translation}

After obtaining the translations and the summary version in Portuguese, the instrument was translated back into English by another translator whose mother tongue was English and who was fluent in Portuguese. This translator was not aware of the concepts involved in the research and also produced a written report on the difficulties encountered and the justification of the choices made in the process of the reverse translation or back translation (BT).

\section{Stage IV: Review by an expert committee}

A committee of experts was organized that comprised a physical therapist, a nurse, a pharmacist, a psychologist, a social worker and a physical educator. All of these professionals held doctoral degrees and had experience in the gerontology field. A doctoral student (with a background in physical therapy) with experience in public health and gerontology was also part of the committee and was the author responsible for the research. On the day of the meeting, everyone had access to the translations, the summary version and the original version of the questionnaire for analysis and discussion.

In 2 meetings, an attempt was made to meet the 4 equivalences suggested by Beaton et al. ${ }^{27}$ : semantic, idiomatic, experiential and conceptual equivalence. The role of the expert committee was to consolidate all the versions of the questionnaire and to develop the penultimate version for the field tests during the pretest stage.

\section{Stage V: Pretest}

The pretest was administered in 30 elderly people ( $\geq 65$ years old) selected by convenience who met the inclusion criteria of the study. The elderly people were interviewed individually with the pretest version of the FRAQ, and they were then asked about the difficulties in understanding the items, the misunderstanding of words and/or the clarity of the response options. Feedback was requested for improvements in the final version of the instrument. The questions not understood by $15 \%$ or more of the participants were reformulated.

\section{Stage VI: Submission of documentation to the authors}

Stage VI was the last stage and consisted of the submission of all the documentation of the translation of the original questionnaire and the adaptation process for evaluation by the original authors of the FRAQ.

\section{Evaluation of the psychometric properties of the FRAQ-Brazil}

To evaluate the reliability of the FRAQ-Brazil, 120 people aged 65 years or older who were enrolled in the FHP of the city of Londrina, Parana State, Brazil were interviewed. They were randomly selected from the records of the community health agents. The socio-demographic information of the participants was collected in a specific questionnaire.

The FRAQ was applied by 2 independent and previously trained interviewers with experience in the physical therapy field (examiners 1 and 2) on the same day with an interval of 30 to 60 minutes between the evaluations to assess the inter-rater reliability. After 2-7 days, examiner 1 reapplied the questionnaire to assess the intra-rater reliability. All 3 interviews were conducted in the homes of the elderly people.

The 2 examiners were aware of the study's methodology, but they were not permitted communicate with each other. Additionally, to avoid influencing the examiners, each questionnaire was scored only at the end of the entire data collection, i.e., after the third interview. 


\section{Data analysis}

The internal consistency was estimated with Cronbach's alpha coefficient, and the following categories were considered: $\alpha \geq 0.9$, excellent; $0.8 \leq \alpha<0.9$, good; $0.7 \leq \alpha<0.8$, acceptable; $0.6 \leq \alpha<0.7$, questionable; $0.5 \leq \alpha<0.6$, poor and $\alpha<0.5$, unacceptable ${ }^{28}$. To assess the intra-and inter-rater reliability, the Kappa coefficient was used for the nominal categorical variables. Values of 0-0.20 had a poor reliability; values of $0.21-0.40$ were reasonably reliable; values of $0.41-0.60$ were considered moderately reliable; values of $0.61-0.80$ were substantially reliable, while values greater than 0.81 were considered to have an excellent or nearly perfect reliability ${ }^{29}$.

Regarding the numerical variables, the intraclass correlation coefficient, ICC, (2-way mixed model $)^{30-32}$ and the respective $95 \%$ confidence intervals for each ICC value were used. ICC values of $<0.40$ were considered to be poor, $0.40 \leq \mathrm{ICC}<0.75$ were reasonable to good and an ICC $\geq 0.75$ indicated an excellent reliability ${ }^{31,32}$. The Bland and Altman agreement tests were also used according to these authors' guidelines ${ }^{33}$, which allows visualizing the mean difference between the measurements and their respective $95 \%$ confidence intervals, the extreme limits of agreement and the standard deviation of the mean difference.

The statistical significance was set at $5 \%(p<0.05)$ in all the tests. The analyses were performed using the SPSS ${ }^{\circledR}$ (Statistical Package for Social Sciences, version 15.0) and Graphpad Prism 5.0 software programs.

\section{Results}

The process of translation and cultural adaptation produced the Brazilian version of the FRAQ (Appendix 1). The $\mathrm{T} 1$ and $\mathrm{T} 2$ versions presented few differences, which were resolved in the synthesis T12 (Table 1) by prioritizing the use of terms and expressions more familiar to the Brazilian population. The back-translated version was very similar to the original, and only minor changes in grammatical structures were required.

The results of the cultural adaptation performed by the expert committee are shown in Table 2 . The committee's work was essential in acquiring the semantic, idiomatic, conceptual and experiential equivalences, thus obtaining the pretest version via consensus among the team. Some terms were replaced by similar ones because the original items are not among the activities normally performed by the Brazilian population, such as walking in the snow and taking a bath. Although the FRAQ is a self-administered questionnaire, it was unanimously decided that an interview would be the best way to use the instrument in Brazil.

The order of questions 21 and 15 was switched to "confuse" or prevent the induction of only positive responses. Regarding question 16, which contained examples of drugs with commercial names, all the titles were removed because the names did not correspond to the drugs used in Brazil and to keep the participant from being limited to only the mentioned drugs.

In the administration of the pretest version to 30 elderly people, there was no need for reformulations because all of these participants understood the questions. The sociodemographic features of the 120 elderly persons who participated in the evaluation of the psychometric properties are described in Table 3. The majority were female (74.2\%) with mean age of 75 years. Cronbach's alpha coefficient demonstrated excellent internal consistency: $\alpha=0.95$.

The Kappa coefficient was excellent regarding the evaluation of the intra-rater reliability, while for the inter-rater reliability, the Kappa coefficient indicated substantial reliability according to the Cicchetti et al. ${ }^{29}$ classification. As for the numerical variables, the test-retest intra-rater and inter-rater reliabilities were considered excellent ${ }^{31,32}$, with $\operatorname{ICC}(3,1)=0.91$ and $\operatorname{ICC}(3,1)=0.78$, respectively. All the values presented had $\mathrm{p}<0.0001$, demonstrating statistically significant results (Table 4).

The mean differences, the standard deviations of the mean differences and the extreme limits of agreement are shown in the Bland-Altman scatter plot (Figure 1).

\section{Discussion}

There is a great interest in the scientific community in developing questionnaires that assess health status. Despite the growing number of developed and applied scales and instruments, not all of them are available in different countries and different languages ${ }^{34}$. Generally these instruments are found in English, which requires a process of translation and transcultural adaptation as well as the analysis of the measurement properties of the instruments ${ }^{35,36}$.

Cruz et al. ${ }^{37}$ describe the existence of international instruments that are not available for Brazilian researchers, which demonstrates the need for the adaptation and validation of the new scales. It is noteworthy that instruments with the same goal as 
Table 1. Modifications carried out during the translation period.

\section{Questionnaire Item - term}

Several questions - Seniors

Q2 - Do you feel you are at risk for falling at any given moment?

\begin{tabular}{|c|c|c|}
\hline Q3 - Stubbing toe & $\begin{array}{l}\text { T1 - Stub one's toe } \\
\text { T2 - Twist one's toe }\end{array}$ & Stub one's toe \\
\hline Q8 - Knitted slippers & $\begin{array}{l}\text { T1 - Knitted slippers } \\
\text { T2 - Knitted flip-flops }\end{array}$ & Knitted slippers \\
\hline Q8 - Lace up walking shoe & $\begin{array}{l}\text { T1 - Shoes with shoelaces } \\
\mathrm{T} 2 \text { - Lace up walking shoe }\end{array}$ & Lace-up walking shoe \\
\hline Q12 - Stroke & $\begin{array}{l}\mathrm{T} 1 \text { - Stroke } \\
\mathrm{T} 2 \text { - cerebrovascular } \\
\text { accident }\end{array}$ & Stroke \\
\hline Q16 - "nerve pills" & $\begin{array}{l}\text { T1 - "Anxiolytics" } \\
\text { T2 - "Nerve pills" }\end{array}$ & "Nerve pills" \\
\hline $\begin{array}{l}\text { Q20 - When getting out of bed, it is best } \\
\text { to: }\end{array}$ & $\begin{array}{l}\text { T1 - When you get up, it is better to: } \\
\text { T2 - When you get out of bed, it is better } \\
\text { to: }\end{array}$ & When you get up, it is better to: \\
\hline Q21 - Salty potato chips & $\begin{array}{l}\mathrm{T} 1 \text { - Salty potato chip } \\
\mathrm{T} 2-\text { Salty potato chips }\end{array}$ & Salty potato chips \\
\hline $\mathrm{Q} 22-\ldots$ is more likely & $\begin{array}{l}\mathrm{T} 1-\ldots \text { has/have higher } \\
\text { probability } \\
\mathrm{T} 2-\ldots \text { it is more likely }\end{array}$ & $\begin{array}{l}\ldots \text { has/have higher } \\
\text { probability }\end{array}$ \\
\hline
\end{tabular}

Version T12
Elderly T2 - Elderly at any given moment? Do you feel you are at risk of falling at Do you feel you are at risk of falling $\mathrm{T} 2$ - Do you feel you are at risk of falling any moment? at any moment?
T1 - Knitted slippers

$\mathrm{T} 1$ - Shoes with shoelaces

- Lace up walking shoe

accident

T1 - "Anxiolytics"

Nerve pills"
T1 and T2

of falling at

T1 - Older people 
the FRAQ are not available in the Brazilian literature, i.e., instruments that evaluate the perception of the risk of falls in the elderly.

However, specific tests of balance and postural control that allow the identification of the clinical

Table 3. Sociodemographic characteristics of the sample.

\begin{tabular}{lcc}
\hline Gender & $\mathbf{n}$ & $\mathbf{\%}$ \\
Female & 89 & 74.2 \\
Male & 31 & 25.8 \\
Age group & & \\
$65 \vdash 75$ & 58 & 48.3 \\
75 F 85 & 51 & 42.5 \\
$85 \vdash$ & 11 & 9.2 \\
Schooling & & \\
No schooling & 15 & 12.5 \\
To $4^{\text {th }}$ grade & 68 & 56.7 \\
From $5^{\text {th }}$ to $8^{\text {th }}$ grade & 12 & 10.0 \\
High school & 13 & 10.8 \\
Higher education & 12 & 10.0 \\
Total & $\mathbf{1 2 0}$ & $\mathbf{1 0 0 \%}$ \\
\hline
\end{tabular}

predictors of the risk of falls in elderly people, such as the Functional Reach Test (FRT) ${ }^{38}$, the Berg Balance Scale (BBS) $)^{39,40}$, the Time Up and Go test (TUG) ${ }^{40}$ and the Tinetti's balance test (Performance Oriented Mobility Assessment - POMA) $)^{41}$, are available to researchers and clinicians. In this context, the Falls Efficacy Scale - International should be emphasized because this instrument is already adapted for use in Brazil (FES-I-Brazil) ${ }^{42}$ and presents excellent psychometric properties, which assess the selfefficacy related to falls; the FES-I-Brazil is useful for understanding the reasons why the elderly develop a fear of falling and identifying the elderly persons who are more susceptible to falling.

Some studies have been performed to present some of the main methodological issues and problems associated with the translation of questionnaires for use in the transcultural research relevant to health professionals ${ }^{43,44}$. Although there are different methods ${ }^{45,46}$, some instruments have specific protocols for their translation and adaptation, as occurs for the Short-Form Health Survey (SF-36) ${ }^{47}$, the Western Ontario Rotator Cuff Index (WORC) $)^{48}$ and the Motor Function Measure Scale (MFM) ${ }^{49}$, among others. In this study, the Beaton et al. ${ }^{27}$ method was chosen

Table 4. Reliability tests: Kappa coefficient and Intraclass Correlation Coefficient.

\begin{tabular}{lcccc}
\hline & \multicolumn{2}{c}{ Kappa coeficient } & \multicolumn{2}{c}{ ICC (model 2-way mixed) } \\
& Kappa & {$[95 \% \mathbf{C I}]$} & ICC (3,1) & {$[\mathbf{9 5 \%} \mathbf{C I}]$} \\
Intra-rater & $0.89^{*}$ & {$[0.87-0.91]$} & $0.91^{*}$ & {$[0.84-0.94]$} \\
Inter-rater & $0.76^{*}$ & {$[0.73-0.79]$} & $0.78^{*}$ & {$[0.69-0.84]$} \\
\hline
\end{tabular}

${ }^{*} \mathrm{p}<0.0001 ; \mathrm{ICC}=$ Intraclass Correlation Coefficient; $\mathrm{CI}=$ Confidence Interval.
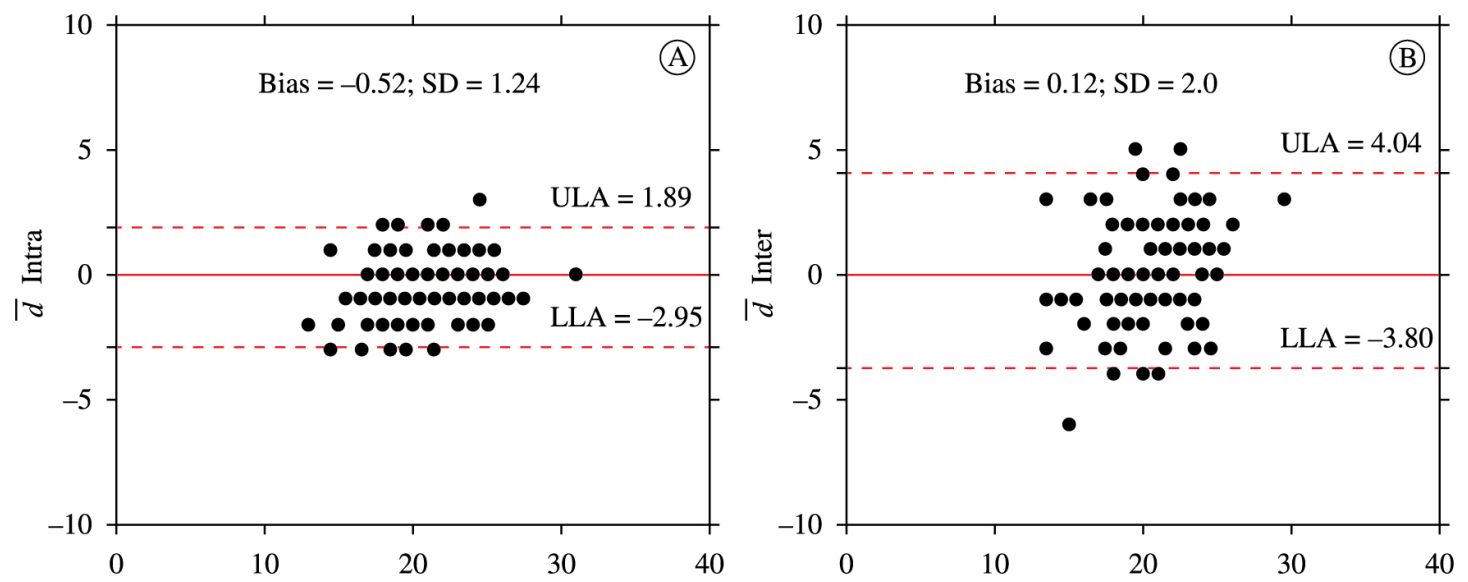

Figure 1. Bland-Altman plot ( $\mathrm{A}=$ intra-rater; $\mathrm{B}=$ inter-rater). SD=Standard Deviation; ULA=Upper Limit of Agreement; LLA=Lower Limit of Agreement. 
because this method is complete, has excellent quality, is the most accepted and used internationally and is the evaluation method used in recent systematic reviews of studies on transcultural adaptations and the evaluation of measurement properties ${ }^{50-53}$.

Each society has its own beliefs, attitudes, habits, behaviors and social habits. These features guide people regarding who they are, how they should behave and what they should do and should not do. These rules or concepts reflect the culture of a country and differentiate one country from another ${ }^{47}$. The items of a questionnaire should not only be linguistically well translated but also must be adapted culturally to maintain the content validity of the instrument ${ }^{35}$. In the process of the adaptation of the FRAQ, the role of the expert committee was critical in this regard, ensuring experiential equivalence by replacing habits such as taking a bath and walking on the snow because these activities do not correspond to the Brazilian reality.

Another adaptation that was required was in the item "Knitted slippers", translated by T1 as "pantufas de tricô" (knitted slippers) and by T2 as "chinelos de tricô" (knitted sandals), which in the final version with the adjustments by the expert committee appeared as "chinelo de borracha, tecido ou lâ" (rubber, fabric or wool sandals) because, in Brazil, the use of slippers is common among the elderly, so the presence of this type of footwear among the answer options was considered relevant.

In semantic equivalence, i.e., the evaluation of grammar and vocabulary, the words that do not have a literal translation of similar meaning must be translated into Portuguese terms that represent an equivalence of meaning ${ }^{54}$. In this context, the most complex item for translation in the FRAQ was "laceup walking shoe", which in the synthesized version appeared as "sapato de caminhada com cadarço" (walking shoe with laces) and, after the committee discussion, appeared as "tênis" (sneakers). Another adapted topic was "nursing home", which was translated as "casa de repouso" (nursing home), but in the final version, the word "asilo" (asylum) was added, a term more widely used in Brazil; in the end, the term appeared as "asilo ou casa de repouso" (asylum or nursing home).

Beaton et al. ${ }^{27}$ reported that idiomatic equivalence addresses the difficulties in translating the colloquial expressions of a given language, seeking an equivalence in the target version. The expression "stubbing toe", which was translated as "topar o dedo do pê" (bumping toe), had to be adapted for better understanding and clarity to "dedo do pé machucado/ batido" (hurt/hit toe).
There were no difficulties in the conceptual equivalence of the FRAQ because all the items used had the same concepts. Often words represent different concepts or meanings across cultures. For example, the meaning of "ver a sua família tanto quanto você gostaria" (see your family as much as you would like to) would be different in cultures with different concepts of what a "family" is ${ }^{27}$.

The decision to convert the FRAQ, originally a self-administered questionnaire, into an interview format was based on the low educational level still present among the elderly in Brazil. According to Orfale et al..$^{55}$, many Brazilian questionnaires are administered as an interview or provide some instructions for the completion of the questionnaire due to the lack of practice of the patients in completing self-administered questionnaires and/or the low educational level; process already observed in other questionnaires translated into Brazilian Portuguese $^{47,56}$.

Cronbach's alpha coefficient was presented by Cronbach $^{57}$ in 1951 as a way to estimate the reliability of a questionnaire administered in a research study. Alpha measures the correlation between the answers in a questionnaire by analyzing the answers given by the interviewees. Because all the items of a questionnaire use the same measurement scale, the $\alpha$ coefficient is calculated from the variance of the individual items and the variance of the sum of the items of each evaluator ${ }^{58}$. The internal consistency of the Brazilian FRAQ yielded an $\alpha=0.95$, which ensures that the adjustments that were made maintained the homogeneity of the instrument components.

The evaluation questionnaires must be reproducible over time, i.e., they should produce the same or similar results for 2 or more administrations with the same patient, assuming that his/her clinical condition has not changed ${ }^{59}$. In the analysis of the intra-and inter-rater reliability of the FRAQ, excellent results were obtained according to the ICC. The Kappa coefficient was another statistical measure that demonstrated excellent and substantial reliability, with values of 0.89 (intra-rater) and 0.76 (inter-rater) for the categorical variables.

Although many reliability studies present only the ICC, this measure alone does not provide enough information for this type of study; thus, the additional use of the Bland and Altman ${ }^{52}$ method is recommended. The Bland and Altman test provides a figure in which the size and the amplitude of the differences in the measurements and the errors or outliers can be easily interpreted. In addition, this method presents the values of the confidence intervals for the mean differences and the limits of agreement ${ }^{60}$, 
the latter of which supports the clinical decision. In the analysis of the FRAQ, the data indicated a good agreement with a bias near zero and small limits of agreement.

Because the FRAQ has not yet been translated and adapted for other countries and other languages, it was not possible to compare the difficulties found in the processes of translation and adaptation and the measurement properties with other cultures. Regarding the responsiveness evaluation, because the FRAQ is a questionnaire about awareness/knowledge, the development of a clinical trial in health education is planned in the near future, which will measure this attribute and contribute to the increased awareness of the risk of falling among the elderly.

The first step to reduce the number of falls among elderly people is an awareness of the risk factors. In this sense, the application of the FRAQ will identify such lack of knowledge, and from this revelation, an awareness of the risks that are ignored by the participants will help to target more efficient prevention programs. It is recommended that the FRAQ be used by public health professionals working closely with the elderly, such as community health workers, who can be trained regarding the risk factors for falls and, thereby, provide more qualified assistance and contribute significantly to the reduction of the number of falls among the elderly.

\section{Conclusion}

The translation of the FRAQ into the Portuguese language and the cultural adaptation of the FRAQ for the elderly Brazilian population were successfully performed following internationally accepted methodological standards. The Brazilian version of the FRAQ maintained semantic, idiomatic, cultural and conceptual equivalences and demonstrated excellent reliability and internal consistency, which makes the FRAQ a useful tool to evaluate the awareness of the risk of falling among Brazil's elderly.

\section{Acknowledgements}

The authors would like to acknowledge all the elderly persons and the professionals who participated and collaborated in this study.

\section{References}

1. Siqueira FV, Facchini LA, Piccini RX, Tomasi E, Thumé E, Silveira DS, et al. Prevalência de quedas em idosos e fatores associados. Rev Saúde Pública. 2007;41(5):74956. http://dx.doi.org/10.1590/S0034-89102007000500009
2. Veras R. Envelhecimento populacional contemporâneo: demandas, desafios e inovações. Rev Saúde Pública. 2009;43(3):548-54. http://dx.doi.org/10.1590/ S0034-89102009005000025

3. Instituto Brasileiro de Geografia e Estatística - IBGE Perfil dos Idosos Responsáveis pelos Domicílios no Brasil. Rio de Janeiro: Ministério de Planejamento, Orçamento e Gestão, Diretoria de Pesquisa; 2002.

4. Almeida MF, Barata RB, Montero CV. Prevalência de doenças crônicas auto-referidas e utilização de serviços de saúde, PNAD/1998, Brasil. Ciênc Saúde Coletiva. 2002;7(4):743-756. http://dx.doi.org/10.1590/ S1413-81232002000400011

5. Sociedade Brasileira de Geriatria e Gerontologia - SBGG. Projeto Diretrizes. Quedas em idosos: prevenção [Internet]. [cited 2012 Aug]. São Paulo: Associação Médica Brasileira e Conselho Federal de Medicina. Available from: http://www.projetodiretrizes.org.br/ livro.php.

6. Brasil. Ministério da Saúde. Quedas de idosos: SUS gasta quase R\$ 81 milhões com fraturas em idosos em 2009 [Internet]. [cited 2011 Nov]. Available from: http://portal.saude.gov.br/portal/saude/visualizar_texto. cfm?idtxt=33674\&janela $=1$.

7. Perracini MR, Ramos LR. Fatores associados a quedas em uma coorte de idosos residentes na comunidade. Rev Saúde Pública. 2002;36(6):709-16. http://dx.doi org/10.1590/S0034-89102002000700008

8. Siqueira FV, Facchini LA, Silveira DS, Piccini RX, Tomasi E, Thumé E, et al. Prevalence of falls in elderly in Brazil: a countrywide analysis. Cad Saúde Pública. 2011;27(9):1819-1826. http://dx.doi.org/10.1590/ S0102-311X2011000900015

9. Fabrício SCC, Rodrigues RAP, Costa ML Jr. Causas e consequências de quedas de idosos atendidos em hospital público. Rev Saúde Pública. 2004;38(1):93-9. http:// dx.doi.org/10.1590/S0034-89102004000100013

10. Riera R, Trevisani VFM, Ribeiro JPN. Osteoporose: a importância da prevenção de quedas. Rev Bras Reumatol. 2003;43(6):364-8. http://dx.doi.org/10.1590/ S0482-50042003000600008

11. Fuller GF. Falls in the elderly. Am Fam Physician. 2000; 61:2159-68. PMid:10779256.

12. Rubenstein LZ. Falls in older people: epidemiology, risk factors and strategies for prevention. Age Ageing. 2006;35(2):37-41.

13. Gusi N, Carmelo Adsuar J, Corzo H, Del Pozo-Cruz B, Olivares PR, Parraca JA. Balance training reduces fear of falling and improves dynamic balance and isometric strength in institutionalised older people: a randomised trial. J Physiother. 2012;58(2):97-104. http://dx.doi. org/10.1016/S1836-9553(12)70089-9

14. Sherrington C, Tiedemann A, Fairhall N, Close JC, Lord SR. Exercise to prevent falls in older adults: an updated meta-analysis and best practice recommendations. NSW Public Health Bull. 2011;22(3-4):78-83. PMid:21632004. http://dx.doi.org/10.1071/NB10056

15. Leung DP, Chan CK, Tsang HW, Tsang WW, Jones AY Tai chi as an intervention to improve balance and reduce falls in older adults: A systematic and meta-analytical 
review. Altern Ther Health Med. 2011;17(1):40-8. PMid:21614943.

16. Hanley A, Silke C, Murphy J. Community-based health efforts for prevention of falls in the elderly. Clin Interv Aging. 2011;6:19-25. PMid:21472088 PMCid:PMC3066249.

17. American Geriatrics Society, British Geriatrics Society, American Academy of Orthopaedic Surgeons Panel on Falls Prevention. Guideline for the prevention of falls in older persons. J Am Geriatr Soc. 2001;49(5):664-72. http://dx.doi.org/10.1046/j.1532-5415.2001.49115.x

18. Panel on Prevention of Falls in Older Persons, American Geriatrics Society and British Geriatrics Society (2011), Summary of the Updated American Geriatrics Society/ British Geriatrics Society Clinical Practice Guideline for Prevention of Falls in Older Persons. J Am Geriatr Soc. 2011;59(1):148-157. PMid:21226685. http://dx.doi. org/10.1111/j.1532-5415.2010.03234.x

19. Wiens CA, Koleba T, Jones CA, Feeny DH. The Falls Risk Awareness Questionnaire: Development and Validation for use with older adults. J Gerontol Nurs. 2006;32(8):4350. PMid:16915745.

20. Sadowski C, Nguyen V, Jones CA, Feeny D. Fall risk awareness questionnaire in community-dwelling older adults. In: The American Geriatrics Society Annual Scientific Meeting: Proceedings of the American Geriatrics Society Annual Scientific Meeting; 2010 May 12-15; Florida. J Am Geriatr Soc. 2010; 4suppl:S48.

21. Kottner J, Audigé L, Brorson S, Donner A, Gajeweski BJ, Hróbjartsson A, et al. Guidelines for reporting reliability and agreement studies (GRRAS) were proposed. J Clin Epidemiol. 2011;64(1):96-106. PMid:21130355. http:// dx.doi.org/10.1016/j.jclinepi.2010.03.002

22. Rosner B. Fundamentals of biostatistics. Pacific Grove: Duxbury Thomson Learning; 2000.

23. Instituto Brasileiro de Geografia e Estatística - IBGE [Internet]. Censo Demográfico 2010. [cited 2011 Dec]. Available from: www.ibge.gov.br.

24. Tombaugh TN, McIntyre NJ. The mini-mental state examination: a comprehensive review. J Am Geriatr Soc. 1992;40:922-35. PMid:1512391.

25. Brucki SMD, Nitrini R, Caramelli P, Bertolucci PHF, Okamoto IH. Sugestões para o uso do mini-exame do estado mental no Brasil. Arq Neuropsiquiatr. 2003;61(3B):77781. PMid:14595482. http://dx.doi.org/10.1590/ S0004-282X2003000500014

26. Lourenço RA, Veras RP. Mini-Exame do Estado Mental: características psicométricas em idosos ambulatoriais. Rev Saúde Pública. 2006;4(4):712-9. http://dx.doi. org/10.1590/S0034-89102006000500023

27. Beaton DE, Bombardier C, Guillemin F, Ferraz MB. Guidelines for the process of cross-cultural adaptation of self-report measures. Spine (Phila Pa 1976). 2000;25(24):3186-91. http://dx.doi. org/10.1097/00007632-200012150-00014

28. George D, Mallery P. SPSS for Windows step by step: A simple guide and reference. 11.0 update. 4th ed. Boston: Allyn \& Bacon; 2003.

29. Cicchetti D, Bronen R, Spencer S, Haut S, Berg A, Oliver $\mathrm{P}$, et al. Rating scales, scales of measurement, issues of reliability. J Nerv Ment Dis. 2006;194(8):557-64.
PMid:16909062. http://dx.doi.org/10.1097/01. nmd.0000230392.83607.c5

30. Krebs DE. Declare your ICC type. Phys Ther. 1986;66(9):1431. PMid:3749277.

31. Shrout PE, Fleiss JL. Intraclass correlations: uses in assessing rater reliability. Psychol Bull. 1979;86(2):420428. http://dx.doi.org/10.1037/0033-2909.86.2.420

32. Weir JP. Quantifying test-retest reliability using the intraclass correlation coefficient and the SEM. J Strength Cond Res. 2005;19(1):231-40. PMid:15705040.

33. Bland JM, Altman DG. Statistical methods for assessing agreement between two methods of clinical measurements. Lancet. 1986;1:307-10. http://dx.doi.org/10.1016/ S0140-6736(86)90837-8

34. Duarte PS, Miyazaki MCOS, Ciconelli RM, Sesso R. Tradução e adaptação cultural do instrumento de avaliação de qualidade de vida para pacientes renais crônicos (KDQOL-SFTM). Rev Assoc Med Bras. 2003;49:375-81. http://dx.doi.org/10.1590/S0104-42302003000400027

35. Guillemin F, Bombardier C, Beaton D. Crosscultural adaptation of health-related quality of life measures: literature review and proposed guidelines. J Clin Epidemiol. 1993;46:1417-32. http://dx.doi. org/10.1016/0895-4356(93)90142-N

36. Terwee CB, Bot SD, De Boer MR, Van der Windt DA, Knol DL, Dekker J, et al. Quality criteria were proposed for measurement properties of health status questionnaires. J Clin Epidemiol. 2007;60(1):34-42. PMid:17161752. http://dx.doi.org/10.1016/j.jclinepi.2006.03.012

37. Cruz LN, Polanczyk CA, Camey SA, Hoffmann JF, Fleck MP. Quality of life in Brazil: normative values for the Whoqol-bref in a southern general population sample. Qual Life Res. 2011;20(7):1123-9. PMid:21279448. http:// dx.doi.org/10.1007/s11136-011-9845-3

38. Lopes KT, Costa DF, Santos LF, Castro DP, Bastone AC. Prevalence of fear of falling among a population of older adults and its correlation with mobility, dynamic balance, risk and history of falls. Rev Bras Fisioter. 2009;13(3):2239. http://dx.doi.org/10.1590/S1413-35552009005000026

39. Santos GM, Souza ACS, Virtuoso JF, Tavares GMS, Mazo GZ. Predictive values at risk of falling in physically active and no active elderly with Berg Balance Scale. Rev Bras Fisioter. 2011;15(2):95-101. http://dx.doi.org/10.1590/ S1413-35552011000200003

40. Gonçalves DFF, Ricci NA, Coimbra AMV. Functional balance among community-dwelling older adults: a comparison of their history of falls. Rev Bras Fisioter. 2009;13(4):316-323. http://dx.doi.org/10.1590/ S1413-35552009005000044

41. Tinetti ME. Performance-oriented assessment of mobility problems in elderly patients. J Am Geriatr Soc. 1986;34(2):119-26. PMid:3944402.

42. Camargos FFO, Dias RC, Dias JMD, Freire MTF. Crosscultural adaptation and evaluation of the psychometric properties of the Falls Efficacy Scale - International Among Elderly Brazilians (FES-I-BRAZIL). Rev Bras Fisioter. 2010;14(3):237-43. http://dx.doi.org/10.1590/ S1413-35552010000300010

43. Sperber AD. Translation and validation of study instruments for cross-cultural research. Gastroenterology. 2004;126(Suppl 1):S124-8. 
PMid:14978648. http://dx.doi.org/10.1053/j. gastro.2003.10.016

44. Peters M, Passchier J. Translating instruments for cross-cultural studies in headache research. Headache. 2006;46(1):82-91. PMid:16412155. http:// dx.doi.org/10.1111/j.1526-4610.2006.00298.x

45. Herdman M,Fox-Rushby J, BadiaX. A model of equivalence in the cultural adaptation of HRQoL instruments: the universalist approach. Qual Life Res. 1998;7:323-35. http://dx.doi.org/10.1023/A:1008846618880

46. Hilton A, Strutkowiski M. Translating instruments into other languages: development and testing processes. Cancer Nurs. 2002;25:1-7. http://dx.doi. org/10.1097/00002820-200202000-00001

47. Ciconelli RM, Ferraz MB, Santos W, Meinão I, Quaresma MR. Tradução para a língua portuguesa e validação do questionário genérico de avaliação de qualidade de vida SF-36 (Brasil SF-36). Rev Bras Reumatol. 1999;39(3):143-50.

48. Lopes AD, Stadniky SP, Masiero D, Carrera EF, Ciconelli RM, Griffin S. Tradução e adaptação cultural do WORC: um questionário de qualidade de vida para alterações do manguito rotador. Rev Bras Fisioter. 2006;10(3):309-15. http://dx.doi.org/10.1590/S1413-35552006000300010

49. Iwabe C, Miranda-Pfeilsticker BH, Nucci A. Motor function measure scale: portuguese version and reliability analysis. Rev Bras Fisioter. 2008;12(5):417-24. http:// dx.doi.org/10.1590/S1413-35552008000500012

50. Costa LCM, Maher CG, McAuley JH, Costa LO. Systematic review of cross-cultural adaptations of McGill Pain Questionnaire reveals a paucity of clinimetric testing. J Clin Epidemiol. 2009;62(9):934-43. PMid:19595572. http://dx.doi.org/10.1016/j.jclinepi.2009.03.019

51. Puga VOO, Lopes AD, Costa LOP. Assessment of cross-cultural adaptations and measurement properties of self-report outcome measures relevant to shoulder disability in Portuguese: a systematic review. Rev Bras Fisioter. 2012;16(2):85-93. http://dx.doi.org/10.1590/ S1413-35552012005000012

52. Hiratuka E, Matsukura TS, Pfeifer LI. Cross-cultural adaptation of the Gross Motor Function Classification System into Brazilian-Portuguese (GMFCS). Rev Bras Fisioter. 2010;14(6):537-44. http://dx.doi.org/10.1590/ S1413-35552010000600013
53. Martins J, Napoles BV, Hoffman CB, Oliveira AS. The Brazilian version of Shoulder Pain and Disability Index: translation, cultural adaptation and reliability. Rev Bras Fisioter. 2010;14(6):527-536.

54. Luft CDB, Sanches SO, Mazo GZ, Andrade, A. Versão brasileira da Escala de Estresse Percebido: tradução e validação para idosos. Rev Saúde Pública. 2007;41(4):606615. PMid:17589759. http://dx.doi.org/10.1590/ S0034-89102007000400015

55. Orfale AG, Araújo PMP, Ferraz MB, Natour J. Translation into Brazilian Portuguese, cultural adaptation and evaluation of the reliability of The Disabilities of the Arm, Shoulder and Hand questionnaire. Braz J Med Biol Res. 2005;38:293-302. http://dx.doi.org/10.1590/ S0100-879X2005000200018

56. Pimenta CAM, Teixeira MJ. Questionário de dor McGill: proposta de adaptação para a Língua Portuguesa. Rev Esc Enf USP. 1996;30:473-83. PMid:9016160. http://dx.doi. org/10.1590/S0080-62341996000300009

57. Cronbach LJ. Coefficient alpha and the internal structure of tests. Psychometrika. 1951;16(3):297-334. http://dx.doi. org/10.1007/BF02310555

58. Hora HRM, Monteiro GTR, Arica J. Confiabilidade em Questionários para Qualidade: Um Estudo com o Coeficiente Alfa de Cronbach. Produto \& Produção. 2010;11(2):85-103.

59. Jenkinson C. Evaluating the efficacy of medical treatment: possibilities and limitations. Soc Sci Med. 1995;41:1395-401. http://dx.doi.org/10.1016/0277-9536(95)00119-R

60. Rankin G, Stokes M. Reliability of assessment tools in rehabilitation: an illustration of appropriate statistical analyses. Clin Rehabil. 1998;12:187-99. http://dx.doi org/10.1191/026921598672178340

\section{Correspondence}

\section{Anália Rosário Lopes}

Rua da Cosmoética, 1847, Jardim Tamanduazinho CEP 85853-755, Foz do Iguaçu, PR, Brasil e-mail: analialopes80@gmail.com 
Appendix 1. Brazilian version of Fall Risk Awareness Questionnaire - FRAQ-Brasil.

\section{Questionário de Percepção dos Riscos de Queda - FRAQ-Brasil}

Este instrumento tem com objetivo avaliar a percepção de idosos quanto aos riscos de queda. Recomendase a aplicação do questionário FRAQ-Brasil na forma de ENTREVISTA.

Nome: Data:

Parte A (Não contém gabarito)

a. Você pode me dizer algumas causas de quedas em pessoas idosas? Favor listar o máximo de causas possíveis.

b. Onde e com quem você recebeu informações sobre riscos de queda?

c. Você sente que corre risco de cair a qualquer momento?

( ) Sim ( ) Não ( ) Não sei

Parte B

As seguintes questões são sobre idosos e quedas. Estamos interessados em sua opinião.

1. Você acha que pessoas idosas (de 65 anos ou mais) têm maior chance de cair do que adultos mais jovens?

( ) Sim ( ) Não ( ) Não sei ( ) Recusou-se a responder

2. Você acha que pessoas idosas podem mudar suas atividades para prevenir quedas?

( ) Sim ( ) Não ( ) Não sei

3. A maioria das quedas resulta em (escolha somente uma opção)

( ) Batida na cabeça

( ) Cortes e contusões

( ) Morte

( ) Bacia e/ou perna quebrada

( ) Nenhum efeito

( ) Dedo do pé machucado/batido

( ) Impossibilidade de fazer atividades regulares

( ) Outros

( ) Não sei

4. As quedas deixam as pessoas idosas menos confiantes de se movimentar.

( ) Verdadeiro ( ) Falso ( ) Não sei

5. Quedas são mais prováveis/comuns de acontecer:
( ) Em casa
( ) Na rua
( ) Em prédio público
( ) Em asilo ou casa de repouso
( ) Num sítio/fazenda
( ) Outros

6. Você acha que a idade mais avançada aumenta o risco de queda de uma pessoa?

( ) Sim ( ) Não ( ) Não sei ( ) Prefiro não responder a esta questão 
Appendix 1. continued...

7. Você acha que usar um andador corretamente pode aumentar a chance de queda?

( ) Sim ( ) Não ( ) Não sei ( ) Prefiro não responder a esta questão

8. O calçado é um importante fator de quedas. Qual tipo de calçado é o mais seguro?
( ) Salto alto
( ) Chinelo (de borracha, tecido ou lã)
( ) Mocassim
( ) Sandálias
( ) Tênis
( ) Botas

9. Qual das seguintes condições apresenta o maior risco de queda?
( ) Entrar e sair do chuveiro
( ) Subir e descer da calçada
( ) Andar sobre piso de cerâmica seco
( ) Andar ao ar livre

10. Você tem maior risco de queda se morar com uma família?

( ) Sim ( ) Não ( ) Não sei ( ) Prefiro não responder a esta questão

11. Você acha que problemas de saúde como o Mal de Alzheimer afetam as chances de queda de uma pessoa idosa?

( ) Sim ( ) Não ( ) Não sei ( ) Prefiro não responder a esta questão

12. Você acha que ter tido um derrame cerebral afeta as chances de queda de uma pessoa idosa?

( ) Sim ( ) Não ( ) Não sei ( ) Prefiro não responder a esta questão

13. Você acha que a surdez aumenta as chances de queda de uma pessoa idosa?

( ) Sim ( ) Não ( ) Não sei ( ) Prefiro não responder a esta questão

14. Você acha que problemas de ouvido (incluindo exemplos como tontura e infecções de ouvido) afetam as chances de queda de uma pessoa idosa?

( ) Sim ( ) Não ( ) Não sei ( ) Prefiro não responder a esta questão

15. Você acha que comer batatas fritas salgadas pode causar quedas?

( ) Sim ( ) Não ( ) Não sei ( ) Prefiro não responder a esta questão

16. Você acha que o uso de bebida alcoólica aumenta o risco de queda?

( ) Sim ( ) Não ( ) Não sei ( ) Prefiro não responder a esta questão

17. Quais dos seguintes medicamentos, quando usados corretamente, você acha que pode aumentar a chance de queda de uma pessoa idosa? (favor marcar TODOS os que se aplicam)
( ) Insulina
( ) Medicamentos para ansiedade preocupação ou estresse, tais como calmantes
( ) Medicamentos para ajudar a dormir
( ) Diuréticos
( ) Medicamentos para ajudar no seu humor
( ) Tranquilizantes que controlam sintomas como alucinação
( ) Penicilina ou outros antibióticos
( ) Medicamentos para baixar a pressão
( ) AAS ou Aspirina uma vez ao dia
( ) Medicamentos para dor ou inflamação
( ) Medicamento para alergia que não causam sono 
Appendix 1. continued...

( ) Medicamentos para dor do tipo morfina

( ) Medicamentos para o coração

( ) Medicamentos para azia ou gastrite

( ) Medicamentos para asma ou bronquite

18. Você acha que uma pessoa idosa que toma vários medicamentos tem maior chance de queda do que aquela que toma somente um medicamento?

( ) Sim ( ) Não ( ) Não sei ( ) Prefiro não responder a esta questão

19. Manter-se fisicamente ativo(a)

( ) Aumenta suas chances de queda

( ) Não tem efeito sobre suas chances de queda

( ) Diminui suas chances de queda

20. Você acha que levantar à noite para ir ao banheiro pode levar a quedas?

( ) Sim ( ) Não ( ) Não sei ( ) Prefiro não responder a esta questão

21. Como é melhor levantar da cama:

( ) Levantar-se imediatamente

( ) Sentar-se na beira da cama por um minuto

( ) Não faz diferença como se levanta da cama

22. Quem você acha que tem maior chance de cair?

( ) Homens de 65 anos ou mais

( ) Mulheres de 65 anos ou mais

( ) Chance de queda igual para homens e mulheres

( ) Não sei

( ) Prefiro não responder a esta questão

23. Você tem maior chance de se machucar quando tem ossos fracos ou quebradiços?

( ) Sim ( ) Não ( ) Não sei ( ) Prefiro não responder a esta questão

24. Você acha que uma pessoa idosa tem maior chance de cair se ela tiver medo de queda?

( ) Sim ( ) Não ( ) Não sei ( ) Prefiro não responder a esta questão

25. Ter um cachorro ativo em casa contribui para quedas?

( ) Sim ( ) Não ( ) Não sei ( ) Prefiro não responder a esta questão

\section{GABARITO}

1. Sim; 2. Sim; 3. Nenhum efeito; 4. Verdadeiro; 5. Em casa; 6. Sim; 7. Não; 8. Tênis; 9. Entrar e sair do chuveiro; 10. Não; 11. Sim; 12. Sim; 13. Sim; 14. Sim; 15. Não; 16. Sim; 17. Medicamentos para ansiedade preocupação ou estresse), tais como calmantes; Medicamentos para ajudar a dormir; Medicamentos para ajudar no seu humor; Tranquilizantes que controlam sintomas como alucinação; Medicamentos para baixar a pressão; Medicamentos para dor ou inflamação; Medicamentos para dor do tipo morfina; Medicamentos para o coração. 18. Sim; 19. Diminui suas chances de queda; 20. Sim; 21. Sentar-se na beira da cama por um minuto; 22. Mulheres de 65 anos ou mais; 23. Sim; 24. Sim; 25. Sim.

\section{PONTUAÇÃO DO QUESTIONÁRIO FRAQ-BRASIL}

A pontuação total do questionário varia de 0 (pontuação mínima) a 32 (pontuação máxima), podendo com uma regra de três simples classificar de $0 \%$ a $100 \%$, sendo que quanto maior a pontuação, melhor a percepção dos riscos de queda. 